ZOOLOGIA 28 (6): 812-818, December, 2011

doi: $10.1590 /$ S1984-46702011000600015

\title{
Three new species of microcaddisflies (Trichoptera: Hydroptilidae) from Brazil
}

\author{
Allan Paulo Moreira Santos', 2; Gabriela Abrantes Jardim' \& Jorge Luiz Nessimian'
}

\author{
${ }^{1}$ Departamento de Zoologia, Instituto de Biologia, Universidade Federal do Rio de Janeiro. Caixa Postal 68044, \\ 21941-971 Rio de Janeiro, RJ, Brasil. \\ 2 Corresponding author. Email: a.santos@ufrj.br
}

\begin{abstract}
Three new species of Hydroptilidae are herein described and illustrated from specimens collected with light traps in the states of Pará and Rio de Janeiro, Brazil. Flintiella carajas sp. nov., from Floresta Nacional de Carajás, shares with F. panamensis Harris, Flint \& Holzenthal, 2002, F. tamaulipasa Harris, Flint \& Holzenthal, 2002, F. yanamona Harris, Flint \& Holzenthal, 2002, and F. manauara Santos \& Nessimian, 2009 a deeply incised phallic apex. However, males can be distinguished by a ventromesal process on segment VII, by lacking dorsal hooked processes on segment IX, by the elongate subgenital plate, and by the lateral lobes of the phallic apex slightly curved laterad. Rhyacopsyche diacantha $\mathbf{s p}$. nov. is closely related to R. yatay Angrisano, 1989 and R. garuhape Angrisano \& Sganga, 2009. All three species have complex inferior appendages with ventral and dorsal lobes. The new species is distinguished by the male genitalia with segment $\mathrm{X}$ two times longer than broad, inferior appendages with the apices obliquely truncate, and a bilobed dorsal lobe on the inferior appendages. Features of the male genitalia of Rhyacopsyche angra sp. nov., R. hagenii and R. dikrosa are similar, but the first species can be distinguished by the inferior appendages truncate apically and produced laterad, and a phallus with the internal tubule hooked subapically and apically.
\end{abstract}

KEY WORDS. Amazon Forest; Atlantic Forest; Flintiella carajas; Rhyacopsyche angra; Rhyacopsyche diacantha.

Hydroptilidae is the most diverse family in the order Trichoptera, with about 2,000 described species found on every habitable continent (Holzenthal et al. 2007). Marshall (1979) reviewed the family and proposed the classification currently accepted, with two subfamilies, Hydroptilinae and Ptilocolepinae. The nominotypical subfamily contains about 70 genera and is widespread in distribution; it comprises six tribes (Hydroptilini, Leucotrichiini, Ochrotrichiini, Orthotrichiini, Neotrichiini, and Stactobiini) (Holzenthal et al. 2007). The subfamily Ptilocolepinae includes only two genera and is restricted to the Holarctic and Oriental regions.

Over 600 microcaddisfly species occur in the Neotropics, but the diversity and distribution of the group are poorly known and many new species in collections remain to be described. Currently, 83 species of Hydroptilidae are recorded from Brazil, but many areas have not been sampled yet. Previously, only two species of Hydroptilidae were known from the state of Pará: Oxyethira brasiliensis Kelley, 1983 and Oxyethira spissa Kelley, 1983. In this paper, we describe two new microcaddisflies from Pará, Flintiella carajas sp. nov. and Rhyacopsyche diacantha sp. nov. Additionally, we describe a new species, Rhyacopsyche angra sp. nov., from the state of Rio de Janeiro, which now has 16 recorded species

\section{MATERIAL AND METHODS}

The specimens were collected with light traps and preserved in $80 \%$ ethanol. Abdomens of males and females were removed and cleared in a heated solution of $10 \% \mathrm{KOH}$ to observe genitalic structures. The morphological terminology follows that proposed by Marshall (1979).

Material examined was deposited in the Coleção Entomológica Professor José Alfredo Pinheiro Dutra, Departamento de Zoologia, Universidade Federal do Rio de Janeiro, Rio de Janeiro (DZRJ), in the Instituto Nacional de Pesquisas da Amazônia, Manaus (INPA), and in the Museu de Zoologia, Universidade de São Paulo, São Paulo (MZSP), as indicated below.

\section{TAXONOMY}

\section{Stactobiini \\ Flintiella Angrisano, 1995}

Flintiella Angrisano, 1995: 502 [type species: Flintiella andreae Angrisano, 1995, original designation]; Harris, Flint \& Holzenthal, 2002: 65 [revision].

Flintiella is a small, exclusively Neotropical genus assigned 
to the tribe Stactobiini. The genus was originally erected for $F$. andreae Angrisano, 1995 from Argentina and Uruguay. In the review of Flintiella, Harris et al. (2002) described eight additional species from Latin America, two from Brazil: $F$. astilla (states of Bahia, Mato Grosso, Paraná, and São Paulo) and $F$. boraceia (state of São Paulo). Recently, SANTos \& Nessimian (2009) described F. manauara from the state of Amazonas, Brazil, and Dumas et al. (2010) recorded F. pizotensis Harris, Flint \& Holzenthal, 2002 from the same state. In this paper, we record the genus Flintiella from the state of Pará, Brazil, with the description of a new species.

\section{Flintiella carajas sp. nov.}

Figs 1-8

Diagnosis. Males of the new species are recognized by having segment VII with a ventromesal process; segment IX reduced ventrally and mesally notched on its posterodorsal margin; segment $\mathrm{X}$ round in dorsal view and bilobed in lateral view; inferior appendages with apical margins round; subgenital plate divided into two apically convergent arms; phallus deeply divided apically, with an ejaculatory duct protruding between the lateral lobes, which are truncate and slightly curved laterad in dorsal view and upturned in lateral view. Females can be recognized by having a ventromesal process on segment VI and by the shape of the bursa copulatrix, slightly narrowed mesally and with round anterior and posterior margins.

Description. Holotype male. Length $1.8 \mathrm{~mm}$ (from tip of head to the apex of wings). General color, in alcohol, light brown. Antennae 18-articulated, with short pale brown setae; distal portion of scape broader than basal portion; pedicel and flagellomeres I-XV terete, apical flagellomere short and with small projection (Fig. 1). Ocelli absent. Posterior setal warts of head short and triangular. Wing venation reduced; wings with brown setae. Tibial spur formula 0,2,3. Abdominal segment VII with short apicomesal process (Figs 2 and 4). Genitalia. Segment VIII annular (Figs 2 and 3). Segment IX reduced ventrally; in dorsal view tapering posteriorly and fused with segment X (Fig. 3); anteriorly with pair of elongate lateral apodemes extended through segment VII; in ventral view with deep, mesal notch on posterior margin (Fig. 2). Segment X short, posterior margin slightly produced mesally in dorsal view (Fig. 3) and bilobed in lateral view (Fig. 4). Inferior appendages somewhat rectangular and round posteriorly in ventral view (Fig. $2)$; in lateral view with a short posterior incision on dorsal margin (Fig. 4). Subgenital plate, in ventral view, divided into two thin contiguous processes which are nearly as long as inferior appendages (Fig. 2); in lateral view thin and elongate (Fig. 4). Phallus tubular, deeply divided distally, ejaculatory duct protruding in the incision (Fig. 5); lateral lobes of phallic apex, in dorsal view, truncate and slightly curved laterad (Fig. 5); in lateral view, lateral lobes upturned distally (Fig. 6).

Variation. Length $1.7-1.8 \mathrm{~mm}(\mathrm{n}=10)$. The male specimens are similar in morphological features.
Female. Length 1.7-1.9 mm $(\mathrm{n}=7)$. Antennae 17-articulated. Coloration and overall appearance of head and thorax as in male. Abdominal segment VI with short ventromesal process (Fig. 7). Genitalia. Segment VII elongate and with anterior portion slightly broader than posterior portion (Fig. 7). Segment VIII almost quadrangular in ventral view and with ring of stout setae on posterior margin (Fig. 7); anterolateral margin with pair of elongate apodemes extending to posterior region of segment VI. Segment IX short and somewhat trapezoidal in ventral view (Fig. 7), lateral margin with pair of elongate apodemes extending to middle of segment VI. Segment X short and round with pair of apical papillae (Fig. 7). Bursa copulatrix with anterior and posterior margins round and slightly narrowing mesad (Fig. 8).

Taxonomic summary. Holotype male, BraziL, Pará: Parauapebas (Floresta Nacional de Carajás, small stream, 06 $04^{\prime} 57^{\prime \prime}$, $50^{\circ} 08^{\prime} 05^{\prime \prime} \mathrm{W}, 642 \mathrm{~m}$, light trap), 06.III.2008, A.P.M. Santos \& N. Ferreira Jr leg. (DZRJ). Paratypes. Same data as holotype, 4 males and 4 females (DZRJ); same data, 2 males and 1 female (MZSP); same data, 2 males and 1 female (INPA); same data, except 26.IX.2007, V.P. Alecrim \& N. Ferreira Jr leg., 1 male (DZRJ); same data, except $06^{\circ} 04^{\prime} 13^{\prime \prime} S, 49^{\circ} 57^{\prime} 00^{\prime \prime} \mathrm{W}$, III.2005, N. Ferreira Jr leg., 1 female (DZRJ).

Distribution. State of Pará, Brazil.

Etymology. This species is named after the locality where specimens were collected, the Floresta Nacional de Carajás.

Remarks. Flintiella carajas sp. nov. shares a deeply divided phallic apex with F. panamensis Harris, Flint \& Holzenthal, 2002, F. tamaulipasa Harris, Flint \& Holzenthal, 2002, F. yanamona Harris, Flint \& Holzenthal, 2002, and F. manauara. The new species differs from $F$. tamaulipasa but is similar to the other three species in the presence of a ventromesal process on segment VII of the male. It can be easily distinguished from $F$. manauara by lacking dorsal processes on segment IX, by having the inferior appendages elongate, and the subgenital plate, in ventral view, divided into two parallel processes. Flintiella carajas sp. nov. is readily distinguished from $F$. panamensis by the shape of segment $\mathrm{X}$ in dorsal view: it is bilobed in $F$. panamensis and simple and round in the new species. The new species differs from $F$. yanamona by the elongate subgenital plate and the lateral lobes of phallus apex broader apically and slightly curved laterad.

\section{Ochrotrichiini Rhyacopsyche Müller, 1879}

Rhyacopsyche Müller, 1879a: 40 [nomen nudum]; Müller, 1879b: 143 [type species: Rhyacopsyche hagenii Müller, 1879, monobasic]; Flint, 1971:516 [revision]; Wasmund \& Holzenthal, 2007: 1 [revision].

Currently, Rhyacopsyche includes 27 described species and is found throughout Latin America (Wasmund \& HolzenthaL 2007). Although Rhyacopsyche species occur in the Amazon 


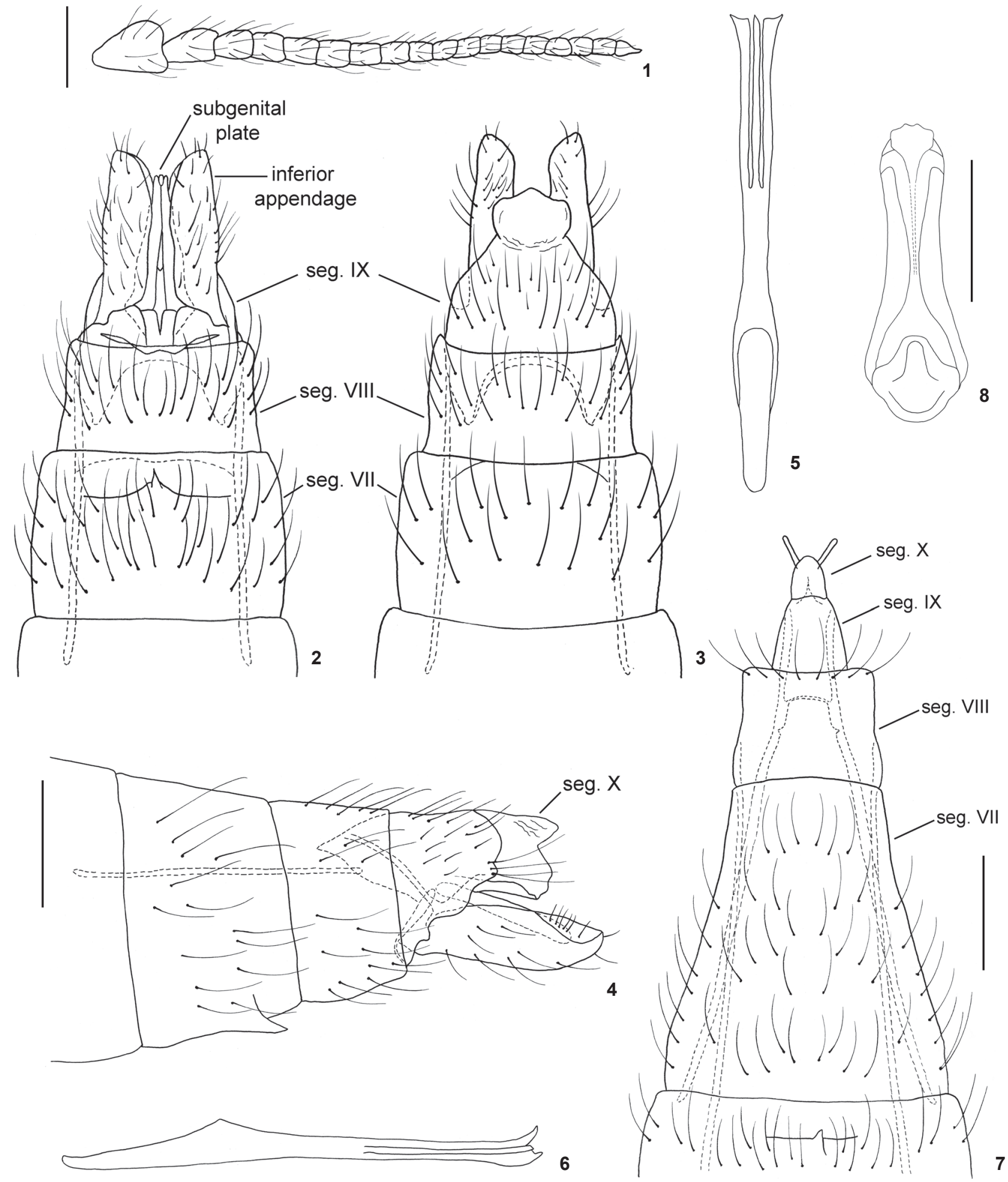

Figures 1-8. Flintiella carajas sp. nov.: (1) male antenna, lateral view; (2) male genitalia, ventral view; (3) male genitalia, dorsal view; (4) male genitalia, lateral view; (5) phallus, dorsal view; (6) phallus, lateral view; (7) female genitalia, ventral view; (8) bursa copulatrix, ventral view. Scale bars: $0.1 \mathrm{~mm}$. 
Region, the genus has not been recorded previously from the Brazilian portion of the Amazon Forest. We record the genus from the Brazilian Amazon, with a new species from the state of Pará. Previously, four species were known from Brazil: Rhyacopsyche bulbosa Wasmund \& Holzenthal, 2007 (states of Minas Gerais, Rio de Janeiro, and São Paulo), R. dikrosa Wasmund \& Holzenthal, 2007 (states of Minas Gerais, Rio de Janeiro, and São Paulo), R. hagenii Müller, 1879 (states of Paraná, Rio de Janeiro, Santa Catarina, and São Paulo), and R. patulosa Wasmund \& Holzenthal, 2007 (state of Rio de Janeiro).

\section{Rhyacopsyche diacantha sp. nov.}

Figs 9-18

Diagnosis. This new species is distinguished by the following features of the male: segment IX in ventral view with a pair of membranous lobes produced posteriorly; inferior appendages complex, with ventral and dorsal processes: dorsal process bilobed apically and bearing two stout spine-like setae, ventral process elongate and round apically; segment X membranous, approximately twice as long as broad in dorsal view, and with the posterior margin slightly emarginate; phallus very elongate and narrow, produced anteriorly and with the ejaculatory duct protruding apically.

Description. Holotype male. Length $2.6 \mathrm{~mm}$ (from tip of head to the apex of wings). General color, in alcohol, dark brown. Antennae 24-articulated. Three ocelli. Posterior setal warts of head oval. Wings with venation typical for genus (Figs 9 and 10) and with long dark brown setae. Tibial spur formula $1,3,4$. Segment VII without ventromesal process. Genitalia. Segment VIII annular. Segment IX, in ventral view, with anterior margin round; posterior margin emarginate and with rigid setae, with pair of membranous lobes originating between inferior appendage and subgenital plate (Fig. 11); in dorsal view, divided mesally into two trapezoidal portions; with pair of thin dorsal processes (Fig. 12). Segment X membranous, approximately twice as long as broad, and slightly excavated posteriorly (Fig. 12). Inferior appendages complex, main body strongly sclerotized, setose, in ventral view wide basally (Fig. 11), and with apex obliquely truncate in ventral and dorsal views (Figs 11, and 12); in lateral view, reniform (Fig. 13); ventral lobe spatulate and with internal margin emarginate and bearing short spine-like setae (Fig. 11); dorsal lobe elongate bearing some apical setae and with short subapical projection bearing two stout spine-like setae (Fig. 12). Subgenital plate short, slightly sclerotized, triangular, striated in ventral view (Fig. 11). Phallus very elongate, extending anteriorly through segment VI; thin in dorsal and lateral views (Figs 14 and 15); ejaculatory duct protruding apically (Fig. 14).

Variation. Length 2.5-2.6 mm $(n=2)$. Other features of the male paratype similar to the holotype.

Female. Length 2.5-2.6 mm $(n=5)$. Antennae 22-articulated. Coloration and overall appearance of head and thorax as in male. Segment VI without ventromesal process. Genitalia. Segment VII annular. Segment VIII elongate, with plumose setae on ventral region (Fig. 16); in dorsal view with short lobes on posterolateral margins (Fig. 17); internally with very long apodemes, reaching anteriorly to abdominal segment II. Segment IX slightly emarginate and with ring of short setae in ventral view; in dorsal view with short mesal incision on posterior margin (Fig. 17); with hooked sclerotized processes (Fig. 17); internally with very long apodemes reaching anteriorly to abdominal segment II. Segment X short, round, with pair of apical papillae (Fig. 17). Bursa copulatrix with anterior sclerite and produced posteriorly into thin tube (Fig. 18).

Taxonomic summary. Holotype male, BrazıL, Pará: Parauapebas (Área de Proteção Ambiental do Igarapé Gelado,

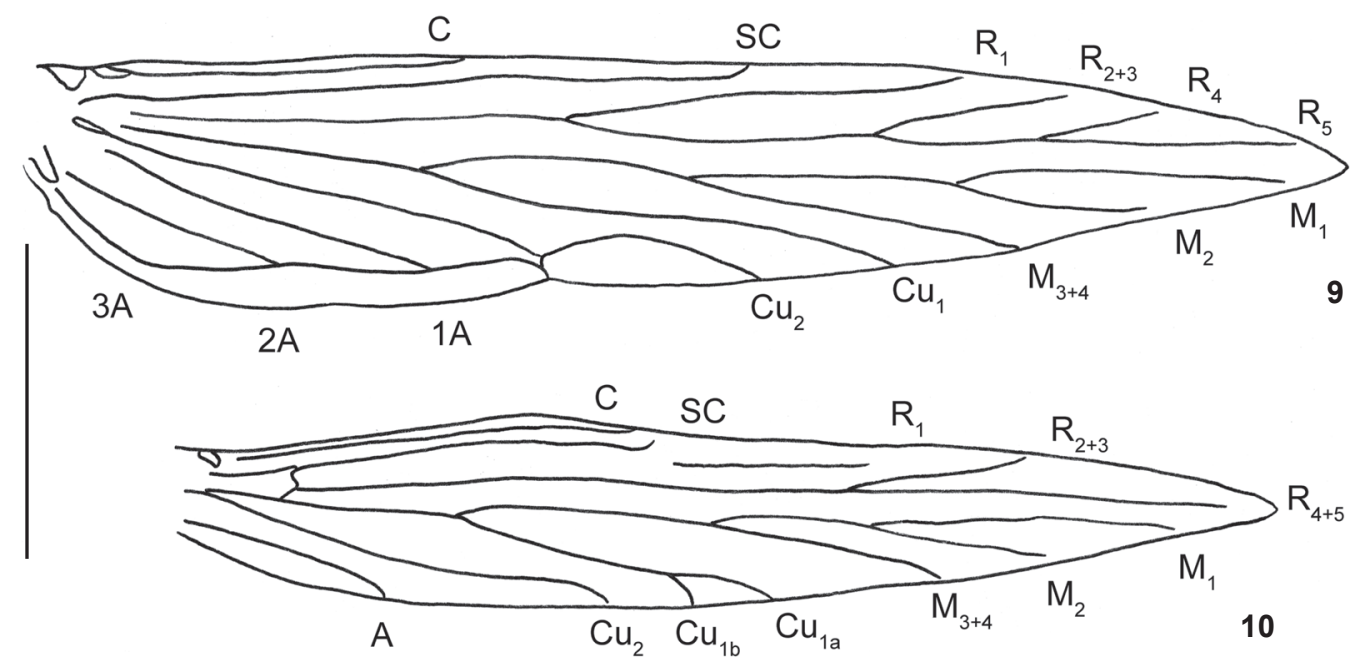

Figures 9-10. Rhyacopsyche diacantha sp. nov.: (9) male forewing; (10) male hind wing. Scale bar: $0.5 \mathrm{~mm}$. 


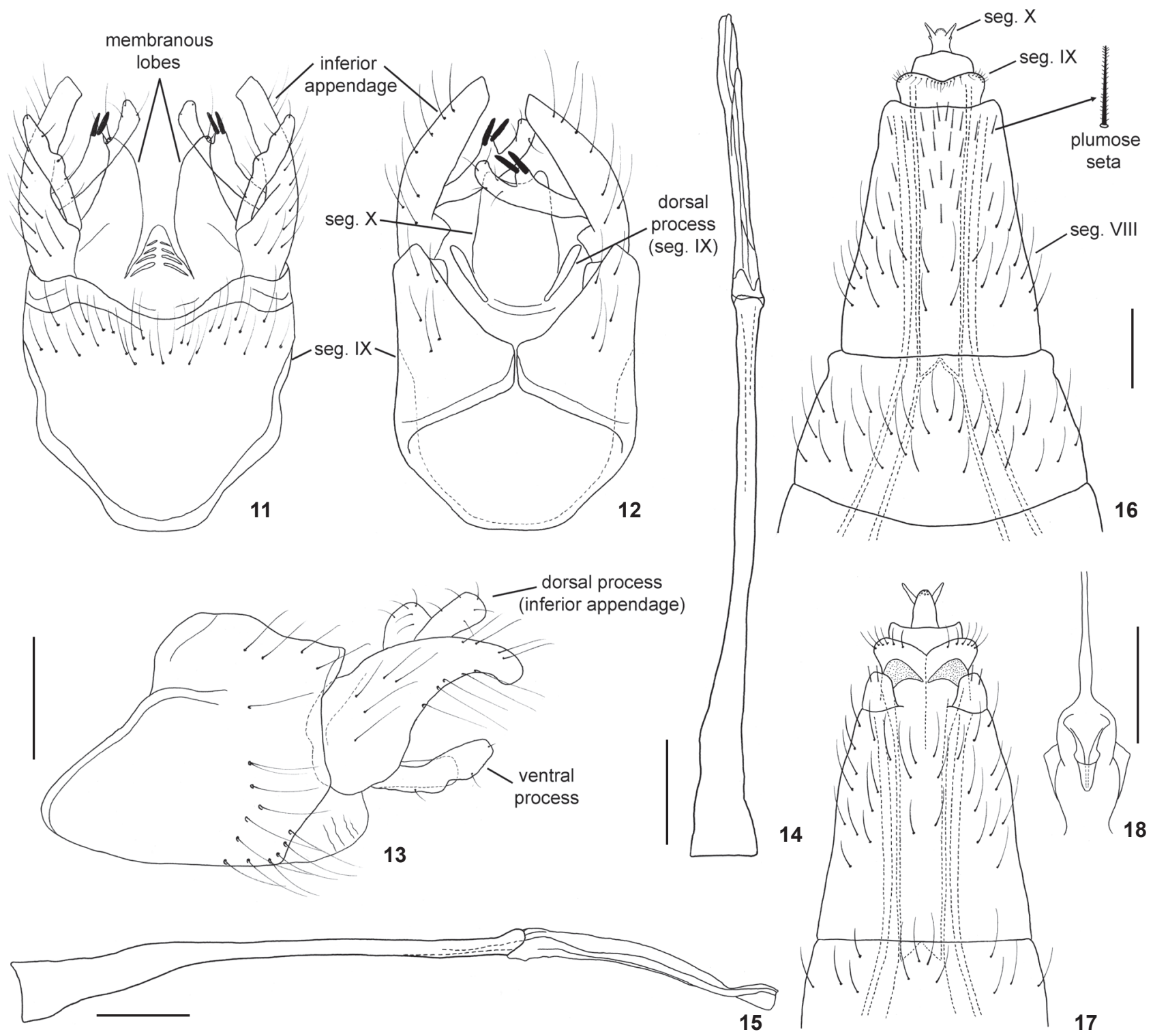

Figures 11-18. Rhyacopsyche diacantha sp. nov.: (11) male genitalia, ventral view; (12) male genitalia, dorsal view; (13) male genitalia, lateral view; (14) phallus, dorsal view; (15) phallus, lateral view; (16) female genitalia, ventral view; (17) female genitalia, dorsal view; (18) bursa copulatrix, ventral view. Scale bars: $0.1 \mathrm{~mm}$.

Barragem do Gelado, 0557'56"S, 50¹3’00”'W, $224 \mathrm{~m}$, light trap), 11.III.2009, lab. Limnologia/UFRJ leg. (DZRJ). Paratypes. Same data as holotype except Lago Pera, 2 females (DZRJ); same data, except, small stream, $05^{\circ} 58^{\prime} 33^{\prime \prime}$ S, 500' $32^{\prime \prime} \mathrm{W}, 215 \mathrm{~m}$, 25.ix.2007, V.P. Alecrim \& N. Ferreira Jr leg., light trap, 2 females (DZRJ); same data, 1 male and 1 female (INPA).

Distribution. State of Pará, Brazil.

Etymology. The species name refers to the spine-like setae on the dorsal lobe of inferior appendages; from the Greek, di (two) and acantha (spine).

Remarks. This new species, R. yatay Angrisano, 1989, and R. garuhape Angrisano \& Sganga, 2009 represent a distinctive species group. They share a similar structure of segment IX and the complex inferior appendages with lobate processes. However, the new species is easily distinguished from both species by having segment $\mathrm{X}$ twice as long as broad and the inferior appendages with apex obliquely truncate, with dorsal process bilobed, and with ventral process elongate. 


\section{Rhyacopsyche angra sp. nov.}

Figs 19-24

Diagnosis. This new species is recognized by features of the male genitalia: segment IX excavated anteriorly and with a pair of short processes bearing spatulate setae in dorsal view; inferior appendages bearing three stout setae on their internal subapical surface, and with apex produced laterad into a round lobe; phallus with internal tubule hooked subapically and apically and covered by membranous sheath with several spicules, phallus apex truncate and produced dorsally in lateral view.

Description. Holotype male. Length $2.8 \mathrm{~mm}$ (from tip of head to the apex of wings). General colour, in alcohol, brown. Antennae 33-articulated. Three ocelli. Posterior setal warts of head oval. Wings with venation typical for genus (Figs 19 and 20) and with long dark brown setae. Tibial spur formula $1,3,4$. Segment VII without ventromesal process. Genitalia. Segment VIII annular. Segment IX with anterior margin excavated mesally, posterior margin slightly emarginated; in dorsal view with pair of small processes bearing short spatulate setae (Figs 21 and 22). Segment $X$ short and membranous, in lateral view, with posterior margin oblique (Fig. 23). Inferior appendages without processes, longer than segment $\mathrm{X}$, apex truncate and produced laterad into a short round lobe in ventral and dorsal views (Figs 21 and 22); in lateral view, apical portion broader than basal portion, with three short spine-like setae on internal subapical surface (Fig. 23). Subgenital plate absent. Phallus very elongate, extending anteriorly through segment VI, covered with short spicules on all its extension (Fig. 24), with an internal tubule bearing two hooks, one subapical and other apical, phallus apex truncate, in lateral view produced dorsally (Fig. 24).

Variation. Length 2.6-3.1 $\mathrm{mm}(\mathrm{n}=10)$. Other features of the male paratypes similar to the holotype.
Female. Unknown.

Taxonomic summary. Holotype male, BraziL: Rio de Janeiro: Angra dos Reis $\left(23^{\circ} 00^{\prime} 23^{\prime \prime} \mathrm{S} 44^{\circ} 29^{\prime} 15^{\prime \prime} \mathrm{W}, 40 \mathrm{~m}\right.$, light trap), 12.v.2002, J.L. Nessimian \& N. Ferreira Jr leg (DZRJ). Paratypes. Same data as holotype, 32 males (DZRJ/MZSP).

Distribution. State of Rio de Janeiro, Brazil.

Etymology. The species name refers to the municipality where the specimens were collected, Angra dos Reis.

Remarks. Rhyacopsyche angra sp. nov. shares features of the male genitalia with $R$. hagenii and $R$. dikrosa. These three species have stout apical setae on the apical area of the inferior appendages, and they also have an internal tubule with a hooked apex in the phallus and the membranous sheath of phallus covered with spicules. However, the new species can be easily distinguished from these and other Rhyacopsyche species by having the apex of inferior appendages produced laterad, dorsal processes on segment IX short, and the internal tubule of the phallus with two hooks, one subapical and the other apical.

\section{ACKNOWLEDGEMENTS}

We are grateful to Nelson Ferreira Jr (IB-UFRJ) and Viviani P. Alecrim for helping in collecting material. We sincerely thank two anonymous reviewers for their comments on this manuscript. Vale Company and the Laboratório de Limnologia (UFRJ) provided assistance in collecting trips at FLONA de Carajás and at APA do Igarapé Gelado. We also thank the Instituto Brasileiro do Meio Ambiente e dos Recursos Naturais Renováveis (IBAMA) for issuing collecting permits. The Coordenação de Aperfeiçoamento de Pessoal de Nível Superior (CAPES) provided a fellowship to APMS and Conselho Nacional de Desenvolvimento Científico e Tecnológico (CNPq) provided fellowships to GAJ and to JLN.

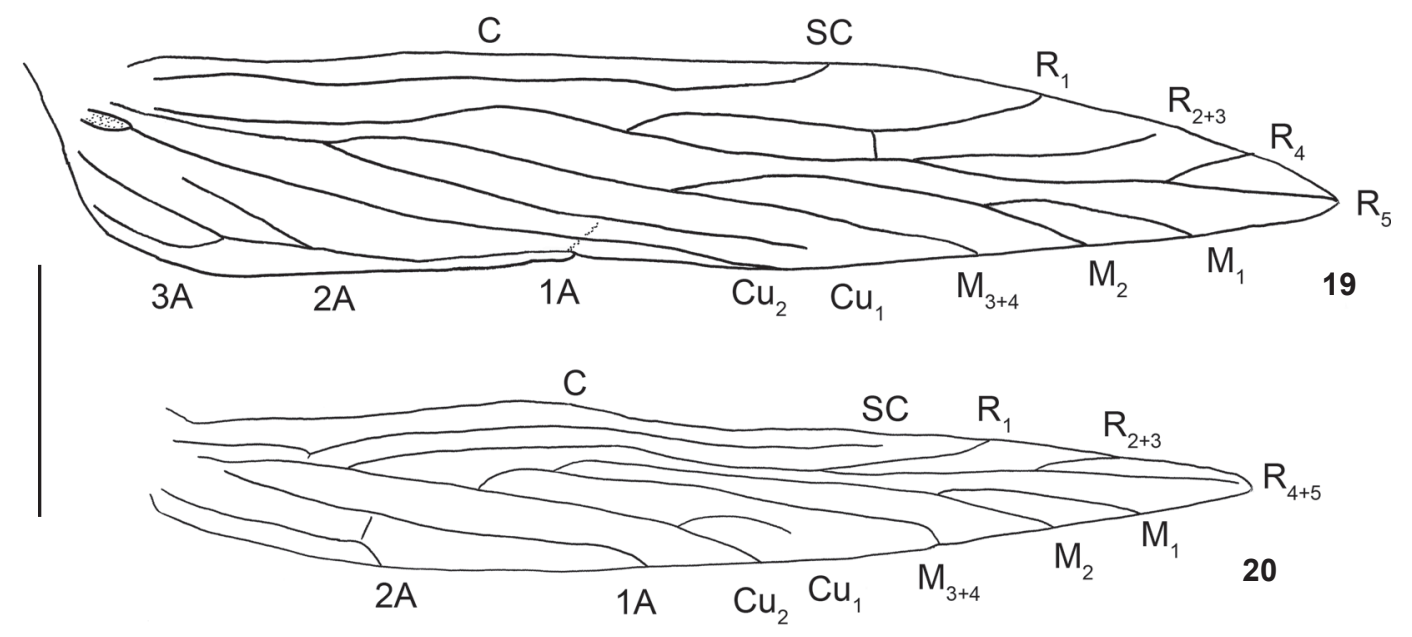

Figures 19-20. Rhyacopsyche angra sp. nov.: (19) male forewing; (20) male hind wing. Scale bar: $0.5 \mathrm{~mm}$. 


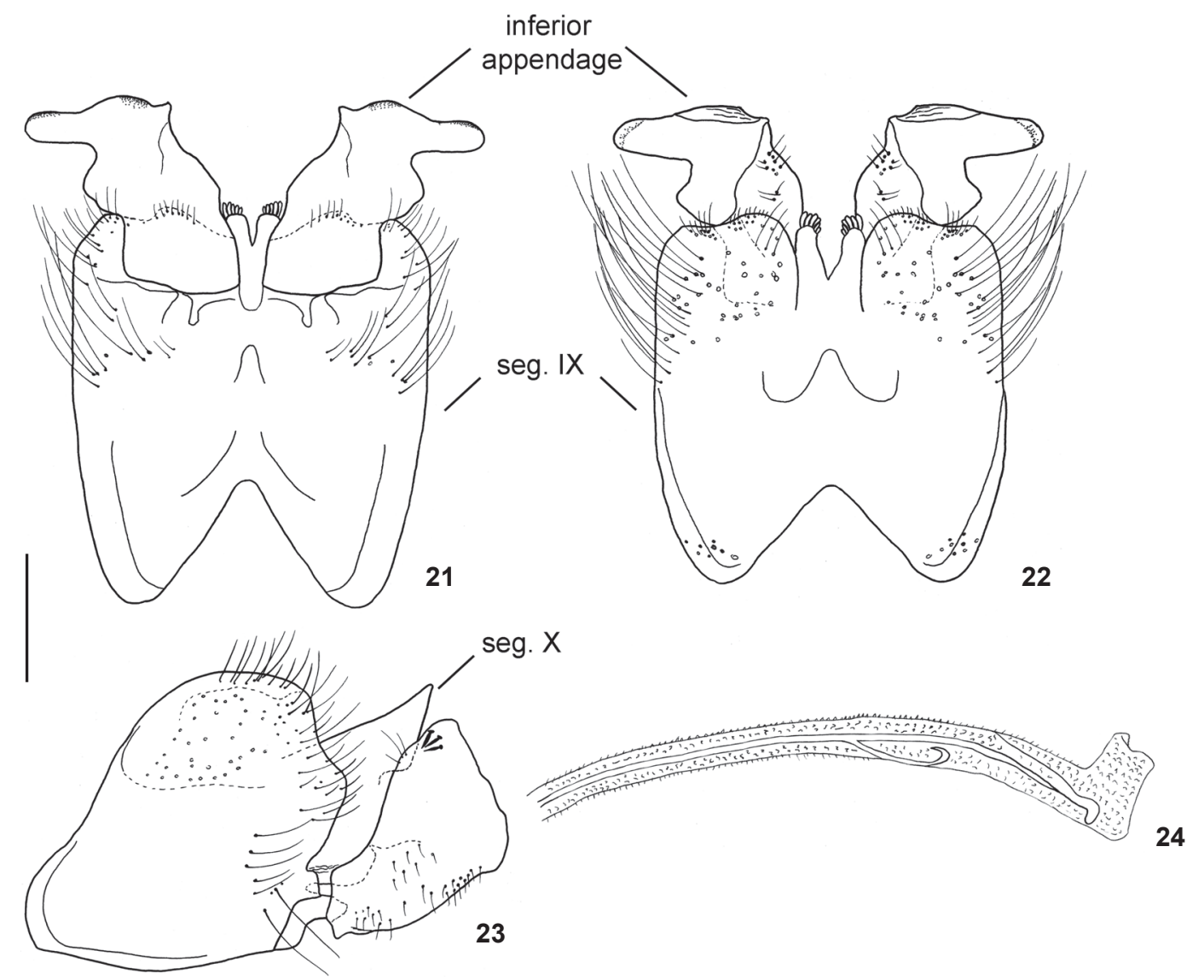

Figures 21-24. Rhyacopsyche angra sp. nov.: (21) male genitalia, ventral view; (22) male genitalia, dorsal view (segment $\mathrm{X}$ is not illustrated); (23) male genitalia, lateral view; (24) distal portion of phallus, lateral view. Scale bar: $0.1 \mathrm{~mm}$.

\section{LITERATURE CITED}

Angrisano, E.B. 1995. Contribucion al conocimiento de los Trichoptera del Uruguay. II. Familia Hydroptilidae. Revista Brasileira de Entomologia 39 (3): 501-516.

Dumas, L.L.; A.P.M. Santos; G.A. Jardim; N. Ferreira Jr; \& J.L. Nessimian. 2010. Insecta, Trichoptera: New records from Brazil and other distributional notes. Checklist 6 (1): 7-9.

FuINT JR, O.S. 1971. Studies of Neotropical caddis flies, XI: the genus Rhyacopsyche in Central America (Hydroptilidae). Proceedings of the Biological Society of Washington 83: 515-526.

Harris, S.C.; O.S. Flint JR \& R.W. Holzenthal. 2002. Review of the Neotropical genus Flintiella (Trichoptera: Hydroptilidae: Stactobiini). Journal of the New York Entomological Society 110 (1): 65-90.

Holzenthal, R.W.; R.J. Blahnik; A.L. Prather \& K.M. KJer. 2007. Order Trichoptera Kirby, 1813 (Insecta), Caddisflies, p. 639698. In: ZhANG, Z.-Q. \& SheAR, W.A. (Eds.), Linnaeus Tercentenary: Progress in Invertebrate Taxonomy. Zootaxa 1668: 1-766.
MarShall, J.E. 1979. A review of the genera of the Hydroptilidae (Trichoptera). Bulletin of the British Museum (Natural History) Entomology Series 39 (3): 135-239.

MÜlLER, F. 1879a. Über Phryganiden. Zoologischer Anzeiger2: 38-40, 180-182, 283-284, 405-407.

Müller, F. 1879b. Notes on the cases of some south Brazilian Trichoptera. Transactions of the Entomological Society of London 1879: 131-144.

Santos, A.P.M. \& J.L. Nessimian. 2009. A new species of microcaddisfly genus Flintiella Angrisano (Trichoptera: Hydroptilidae) from Amazonas State, Brazil. Zootaxa 2004: 65-68.

Wasmund, A.M. \& R.W. Holzenthal. 2007. A revision of the Neotropical caddisfly genus Rhyacopsyche, with the description of 13 new species (Trichoptera: Hydroptilidae). Zootaxa 1634: $1-59$.

Submitted: 16.VIII.2011; Accepted: 18.XI.2011. Editorial responsibility: Gabriel L.F. Mejdalani 